\title{
The Menace of Women Trafficking and the Implications on the Nigerian Society: A Decisive Approach to Halting It
}

\author{
Obuzor Mezewo Emerinwe ${ }^{1}$ Grace A.T Scent, Ph.D ${ }^{2}$ \& CHUKWU, Christian Chima, $\mathrm{PhD}^{3 *}$ \\ 1. Department of Sociology, Faculty of Social Sciences, Rivers State University, Nkpolu, \\ Oronworukwo, Port Harcourt. ORCID: 0000-0001-7836-3977 \\ 2. Department of Sociology and Anthropology, Niger Delta University, Wilberforce Island, Nigeria. \\ ORCID: 0000-0001-8846-6881. \\ 3. Department of Sociology, Novena University, Ogume, Delta State, Nigeria. \\ E-Mail: chukwuchidr@gmail.com; ORCID: 0000-0002-4290-234X;
}

\begin{abstract}
Trafficking in women for sexual exploitation is an economic activity motivated by profit taking, and it has gained notoriety in Nigeria, particularly Rivers State where many families today are selling their daughters into international prostitution as the most lucrative alternative to escape extreme poverty. As a result, the number of young women offering themselves to be trafficked is shocking; they are no more being forced, tricked or threatened into selling sex. Empirically it seems better-paid than other low-skill, labour-intensive professions. A number of questions begging for answers have been raised. Among the questions: What are the causes and consequences of trafficking in women? How can the problem of trafficking in women for profit motives be halted in Nigeria? Why has there been this boom in Nigeria despite being a signatory to the abolition of this menace? Furthermore, what does trafficking in women portend for the socio-economic development and survival of the Nigerian state and citizens? It is in view of these glaring questions that this study intends to proffer solutions. From the findings, the study reveals that aside being an economic activity for profit motives; trafficking in women dehumanizes the dignity of womanhood, and that reinforces the stereotypical views about women as sex objects which can be used and abused by men, and by implication, further entrenching the existing patriarchal societal order. Secondly, there is a significant relationship between trafficking in women and health risks such as infection of HIV/AIDS and psychological trauma. In other words, some of victims contract HIV/AID and ever remain psychologically traumatized and mentally enslaved. Also, the study shows that trafficking in women violates human rights. Victims are not only subjected to violence, threats and other forms of physical and mental abuse, but pathetic and dehumanizing. Based on this, the study concludes that since poverty is often the reason for trafficking in women, economic empowerment programmes via job creations, skills acquisitions and loans without collateral and interest should be a core necessity to free all trapped victims. Finally, the study recommends that poverty, ignorance and unemployment must be addressed by the government to stop people being lured into trafficking. Furthermore, public awareness should be organized with hand bills, pamphlets and other educative materials against trafficking in women and the evils inherent in its activities. The agency responsible for the eradicating the problem of human trafficking must be adequately and promptly funded and logistic support must be given to this agency from the government, non-governmental organizations and the entire local and international communities. In addition, government, NGOs and other wealthy cheerful givers should be encouraged to assist to re-integrate, rehabilitate and counsel victims. What is more, the judiciary must ensure that offenders of this heinous crime against women are apprehended, prosecuted and punished
\end{abstract}

Keywords: Trafficking in women; NAPTIP; Sexual exploitation, Sex slavery, Degradation and Dehumanization of women

DOI: $10.7176 /$ RHSS/10-4-15

Publication date: February $29^{\text {th }} 2020$

\section{INTRODUCTION}

Trafficking in human, particularly women for commercial sexual exploitation is older than the days of Rehab, the prostitute, who assisted the spies in Jericho (Joshua, 2:1), even though her recruitment into the sex trade was never disclosed. Nowadays, and indeed everywhere, trafficking in women for sexual exploitation has become a cancerous ailment that has eaten deep into the structures of most societies of the world, particularly developing societies of Asia and Africa. It is, indeed, going by available statistics, one of the most frightening realities of the moment and a grave violation of human rights. Trafficking in women for purposes of sexual exploitation has existed for many years. The first International Convention on Trafficking was signed in 1904 to address British women being trafficked to brothels in Europe, and Europeans being trafficked to the United States (Refugee Reports (2000). Approximately 120,000 women and children are trafficked into the Europe every year. Worldwide, estimates on criminal activities bordering on trafficked human persons are always imprecise due to 
the illicit nature of the sex trade, but it has been suggested that nearly 30 million live currently in involuntary servitude (Global Slavery Index, 2013) and 600,000 are trafficked per year in the sex industry (Kara, 2009). Trafficking in women otherwise called 'Modern Slavery has produced an estimated 35 million victims from Southeast Asia alone while in Europe, conservative estimates indicate that as many as 120,000 women are trafficked into Western Europe and forced into the sex trade yearly, with half a million currently living in servitude in Western Europe (United Nations Economic and Social Council, 2000). Of these women, 75\% are under the age of 25, of whom a great number are teenagers. The majority of the foreign women in sex trade are from Albania, Romania, Russia and Poland and an increasing number are from African nations (Niklas \& Andreas, 2010). From the foregoing, up to 50 percent of foreign women in the sex trade, according to Belgian authorities, in the country are from Albania ((Niklas \& Andreas,2010). The International Organization for Migration reported that nearly 80 percent of the estimated 10,000 women trafficked into Germany every year came from Central and Eastern Europe and the Newly Independent States. In the same vein, Reports indicate that 40 percent of women in the sex trade in the Netherlands are illegal immigrants from Eastern Europe and Africa (Protection Project, 2002).

These large numbers have sparked public outrage and interest in initiatives to combating trafficking headlong. According to the U.S. Department of State (2012) in 2011, 4,239 out of 7,206 suspects were convicted of trafficking worldwide, and 41,210 trafficking victims were identified. While significant in absolute terms, conviction rates are small in comparison to overall trafficking estimates (at approximately 10 percent). It is in this vein that Amnesty International, a UN commission cited such concerns in its call to legalize all aspects of trafficking in women, namely, supplying, demanding, and mediating (pimping) worldwide (The Guardian, 2013). Agreed, the rule governing trafficking in women vis-à-vis sex trade has long been divisive, and the question was newly re-energized consequent upon Amnesty International's decision, to support its worldwide legalization. However, the moralists fear that legalizing sex trade will not only facilitate and boost trafficking, but debase womanhood. On the contrary, voluntary sex workers, as in the days of Rehab (Joshua, 2:1) who choose to sell sex because it is lucrative, or find themselves unnaturally involved in it due economic circumstance, contend that the validation of sex trade will bring it out of the dark and consequently, improves the opportunities to obtain medical care and also protection from the police in the event of harassments by troublesome clientele. In reality, both sides express disapproval of sex trafficking, but there seems to be little agreement on how to combat the menace. While one side argues that accepting sex trade brings to the open, and ensures safety of participants, the other holds that proscription will be counterproductive as it will no longer be secured as patronizing parties would be prone to abuse not only by customers, but security agencies, the police in particular.

Today, trafficking in women have become threats to Nigeria's global image as the giant of Africa. Based on this, Ashaka (2016) argues that trafficking in women has assumed a transnational trade status, encompassing all the continents in the world. As the fastest growing criminal industry in the world and the world's third largest criminal enterprise, Eun-kyung, Kim (2005) asserts that the existing knowledge about trafficking, particularly in parts of Africa are fractured and fragmented. United Nations Report rates human trafficking as the third most lucrative business to the organized criminal networks after drug and gun running (Ndaguba, 2005). The U.S. State Department in its June 2012 report also views sex trafficking as among the top three revenue sources for organized crime, after trafficking in narcotics and arms, and the United Nations Office on Drugs and Crime (UNODC) estimates that women trafficking generate tens of billions of dollars in profits for traffickers annually. Substantiating this assertion, the US Central Intelligence Agency estimates that traffickers earn approximately $\$ 250,000$ in profit from the work of each trafficked prostituted woman (Osborn, 2001). Prostituted women earn traffickers from $\$ 800$ to $\$ 5,000$ every time they are resold to another organized crime ring (Lord, 2002). Every country in the world is affected by trafficking, either as a country of destination, transit or origin, or in combination. From this perspective, trafficking in women has gained recognition in recent decades as an issue of serious international concern

Obviously, the interest in this study is not necessarily being propelled because of the huge number of trapped victims in the illicit sex industry is difficult to ascertain, but that most countries still deny the magnitude of the inhuman treatments meted out to their nationals, including bestiality for economic motives - having sexual union with dogs! Hold it, the most degrading and dehumanizing is the dangling of bundles of dollars before trafficked victims and instructing them to keep her legs wide open and permitting snakes of a given species to move their tongues across the surface of the victims' clitoris, while photographs are being taken. Most cases, though 
unreported, some victims have been bitten to death by these reptiles! Sickening and an unimaginable state of affairs; in fact, due to the shame and disgrace associated with this illicit sex trade, particularly copulating with dogs, and wriggling one's waist with ecstasy and speaking in tongues as if possessed, while the surfaces of the victims' clitoris are tickled by snakes longish tongues or any other. With this, no country really wants to admit that her citizens are involved in these despicable and inglorious acts which, degrade and dehumanize womanhood for pecuniary reasons. Even if the participation of their nationals is proven, they are quick to deceptively identify these nationals rather as foreigners, or better still, as refugees and linked them to other countries, with maybe one or two countries close to them. Candidly, trafficking is a blot on the landscape of any country because it constitutes an act of assault that results in physical, sexual, or mental harm or suffering to women including threats of such acts, coercion, or arbitrary deprivation of liberty.

Essentially, sex trade has significant implications for international human rights, and international criminal law. Despite all efforts to prevent and punish the perpetrators of this evil against women, the trafficking in women appears to grow higher every year because women, culturally, first of all, are seen, as economic assets to be given out in whatever forms, either in marriage, usually forced marriage or domestic servants, as means of generating revenue for the family's well-being. Strangely enough, this attitude of perceiving women as commodities has been transformed into trafficking them to achieve same economic gains; this evil has gained notoriety in Nigeria, particularly Rivers State where many families today are selling their daughters into international prostitution as the most lucrative alternative to escape extreme poverty. Regrettably, women, generally, are increasingly and disproportionately been affected by poverty worldwide. Corroborating, European Women's Lobby (2001) avers that of the 1.3 billion absolute poor in the world today, $70 \%$ are women and their minor dependents. This poverty is due, in part, to women's lack of access to formal education and job opportunities in their countries of origin. Further, women are hardly beneficiaries of today's world economic regime due to the lack of economic power in their communities and families (UNIFEM, 2002). At the same time, women, being the principal segment of the population is affected by the massive cuts in social spending by governments' economic policy. Following the trend of gender inequities and relative powerlessness of women, they have little to lose, and as a result, are always willing to take greater risks hence, their involvement in sex trade whether voluntarily or otherwise (Swedish Ministry for Foreign Affairs, 2001). Consequent upon this ugly trend, parents, instead of reprimanding their young girls, are often observed encouraging them into sexual relations as a means of improving their economic status.

This archaic attitude of culturally regarding women as economic commodity as a result of patriarchy has attracted the contributions of a significant number of academics and commentators such as Professor Iwe (1985) who observes that the perpetrators of these acts against women are yet to acknowledge that the dignity of women was equal to that of men. By extension, he argues that the splendour of womanhood, which is based on human personality, the prerogative and quality of every woman, is fundamentally, essentially and unquestionably equal to the dignity of man. Furthermore, he affirms that, the truth of this statement is unassailable in spite of sex differences, for human dignity rests not on sex but on personality; and personality as such has no sex. Accepting this position therefore, the modern "re-emergence" of trafficking in women just like slavery of old said to be linked to global economy, is condemnable. Admittedly, the trade presents significant economic opportunity to those who may have limited access to legitimate enterprises, and for whom a form of human capital and commodification of that capital is the most readily available resource that may be profitably exploited.

Trafficking in women is indeed a complex, multi-faceted phenomenon involving multiple stakeholders that have transformed the trade into a demand-driven global business with a huge market for commercial sex. As a global business, the commercial sex industry has greatly expanded and integrated with other aspects of modernization. The demand factors dominating commercial sex work requires a constant supply of women because it is inextricably linked with tourism, both domestic and foreign. According to Corner (2002), some countries are specifically promoted for sex tourism. In the city of Rome, for example, prostitution is not only legal but taxed, bringing in funds for the government. This endorsement, despite its attendant health risks and human rights implications, centers on the huge profits generated through this enterprise to improve the country's economy. Nevertheless, the hypocrisy that seems to exist everywhere is that governments that encourage this type of tourism are not oblivious that it exposes women to different types of health risks, psychological trauma and violation of their fundamental human rights. Perhaps, it is in this light that President Bush, an erstwhile president of the Unites States, declares: "Those who patronize this industry debase themselves and deepen the misery of others." 
Essentially speaking, the profitability of trafficking in women is centered on the distinctiveness of the nationwide market for commercial sex in a given country. As earlier argued, trafficking in women is an economic activity in which participants in it try to make profits (Salt 2000; Salt and Stein 1997). Since profitability is the key interest, business only booms when young women trafficked are sold at favourable market conditions to achieve the desired end (UNODC, 2009). Put differently, a crucial factor for its profitability is built around the legal framework surrounding it. Substantiating, it is impracticable to fight trafficking in women where commercial sex booms through sanctioned prostitution (Aghatise, 2004). While Nigeria may not officially be seen as supporting trafficking in women from where functional sex tourism emerges, the effects of pushing women into becoming commercial sexual workers for exploitation (henceforth trafficking), which has been identified as a form of modern day slavery, on the socio-economic structures of the society have not only been obvious, and devastating, but a serious crime and a gross violation of human rights (European Commission, 2009). By extension, it is a crime against humanity in the statute of the International Criminal Court (Article 7.2). By this, one could contend that trafficking in women is not only a cancerous ailment but an anathema in traditional societies of Africa where mechanical solidarity still holds sway.

As a global social problem, traffickers as greedy and aberrant because we cannot ignore the cruel exploits of the imagery of the trans-Atlantic slave trade in our sub-consciousness alongside willful innocence regarding the trade's continued structural effects in Nigerian society. Thus, the phenomenal responsibility to arrest its spread in the Nigerian society was heightened with the establishment of a Non-Governmental Organization against human trafficking: Women trafficking and Child labour Eradication Foundation (WOTCLEF) in 1999, when media reported that more than four hundred young and underage Nigerian girls were into prostitution in the Netherlands (Nwagbara, 2012). The dehumanizing issue was not that these girls were innocently lured into the sex trade through unscrupulous visa lottery agents, tourism and travel agents, employment agents, corrupt government officials, et cetera for economic benefits, but that they were subjected to degrading inhuman conditions, including forcing them into bestiality. Besides, the inhuman treatment meted out to these women (victims) reminded one of what was obtained in the medieval period when women had no identity of their own. As it were, the concept of womanhood as it is known today did not exist as women were not seen as a distinct social group with any unique characteristics of importance, except of course, being gorgeous and peacock-like in the mode of dressings; life was mainly paternalistic and the father was the ultimate authority on every matter, and exercised complete/total control over the social, economic and physical well-being of the family.

However, with the influence of globalization, the worrying statistics from trafficking shows that an estimated $87 \%$ of women were trafficked (UNODC, 2006) was for commercial sexual activity. This figure, we may argue, is a conservative estimate of the actual number of women trafficked, especially in this age and time where many young girls are willingly offering themselves to be trafficked for pecuniary reasons and this seems to be the most terrifying and dehumanizing aspects of the danger, not necessarily because it has become a purely economic activity in the last three and half decades, but that its assumed status as a modern day slavery with compensations in foreign currencies is worrisome. While exact data are hard to come by, UNESCO (2004) estimates that the number of trafficked persons range from 500,000 to two million per year, and a few organizations has estimated that up to four million persons are being trafficked every year. Going by the trend of the trade, these statistics are conservative estimates of the actual number of women trafficked. For some scholars, worldwide estimates on trafficked human persons, particularly women are always imprecise, but it has been suggested that nearly 30 million of trafficked persons live currently in servitude. Nevertheless, the bone of contention is not the conflicting or varying figures one may have, but the effects of the alarming number of trafficked women on the Nigerian society. Although women and men can become victims of trafficking but the majority of victims are always women because various forms of gender-based discrimination increase their risk of becoming affected by poverty, which in turn puts them at higher risk of becoming targeted by traffickers, who often use false promises of jobs and educational opportunities to recruit their victims (Manbe, 2016). Writing, José Alcalá, M. et al., (2006) state that trafficking has developed into a highly profitable business that generates an estimated US\$7-12 billion per year.

Rather than view trafficking in women as a peculiar trade, prostitution by women has been an integral part of our everyday human existence. Whether or not institutionally, morally or socially condoned, trafficking, just like slavery, has always been with humankind, but the implicit or explicit hypothesis is that modern trafficking in 
women is more widespread and awful, and involves more victims and human degradation, than did the transAtlantic slave trade. Thus, the current debate is whether trafficking in women is worth the controversies it has so far generated because it is like any other business that is highly profitable. Whichever side the debate swing, the disgusting point is that the decision to control one's sexuality is lost and given to anyone who can purchase it without any resistance from the legitimate owner. By implication, it is a leeway to contracting different incurable diseases irrespective of the huge economic profits therein. Basically, as argued by many scholars, these trafficked young women are more vulnerable to HIV and AIDS infection, because:

i) Trafficked women are unable to insist upon condom use.

ii) Trafficked women may be forced to perform those sexual practices most associated with AIDS transmission.

iii) Trafficked persons are forced to have sex with multiple partners, including animals such as dogs. Violent behaviour in commercial sex is common, especially where women or children are forced to have sex against their will. Injuries sustained during forced sex may increase vulnerability to HIV transmission.

Since young girls are equally trafficked, their physically immature bodies are extremely vulnerable to sexual injuries. Such injuries increase their risk of infection to many sexually transmitted diseases (STDs) due to forced and unsafe sexual activities. This heightens the risk of contracting HIV, as Burkhalter (2003) declares, up to a factor of 10. The vulnerability of trafficked women to sexually transmitted diseases is compounded by their inability to receive medical services, and counseling because of their failure to understand or speak the language of the country of their destination.

But as it stands today and as it were yesterday, trafficking in women dehumanizes the dignity of womanhood, and there is absolutely no doubt about that. Corroborating this assertion, Divorkin (1992) declares that when men use women in prostitution, they are expressing a pure hatred for the female body. It is pure as anything on this earth is or ever has been contempt so deep that a whole human life is reduced to a few sexual orifices and he can do anything he wants. Evidently, Divorkin's submission seems to reinforce the stereotypical views about women as sex objects which can be used and abused by men, and by implication, further entrenching the existing patriarchal societal order. This, notwithstanding, it surprises many why the economic gains accruing from the trade seems to have overlooked the fact that Nigeria as a country, is a signatory to all forms of devaluation against women. The puzzle remains that why, out of a sudden, Nigeria has become a country of origin, transit, and destination for all forms of trafficking detrimental to women despite the fact that she has legislated against trafficking of persons? Despite efforts to stamp it out, the menace is still booming and generating millions of naira. What could be behind this hypocrisy? Since the revenues are a function of the price and the number of women trafficked, could it be argued that there is a link between traffickers and our policy initiators? Whose economic empires are these policy makers safe guiding at the detriment of our collective goal of recreating a new discipline Nigerian society? Only a question!

Paradoxically, the hypocrisy inherent in the system is unparalleled. Condemnable as the two-facedness is, section 4 of the Nigerian Trafficking law clearly offers a return to sanity as it empowers the National Agency for the prohibition of trafficking person (NAPTIP) to coordinate all the laws on trafficking in persons in the country to ensure an effective change in morals. What is more, all laws on human trafficking at the state level have come under the national law on trafficking. Furthermore, certain chapters of the constitution, according to Manbe (2016), provide protection for vulnerable groups including women and children. Perhaps, it is important to state that the criminal code in 1904 and the penal code in 1960 criminalized trafficking in Nigeria. But the criminal penal codes did not deal with the issue comprehensively enough as it failed to accurately define what trafficking meant. Addressing this lacuna, section 279 of the Penal Code reads:

Whoever imports, exports removes, buys, sells, disposes, traffics, or deals in any person as a slave or accepts, receives or detains in any person against his will any person as a slave shall be punished with imprisonment for a term which may extend to fourteen year and shall also be liable to a fine.

A cursory look at Section 279 of the Penal Code above implies that the sanctions against infringements of these provisions are too weak to serve as deterrent. As a result, perpetrators of this vicious crime have habitually escaped judgments on discovering the lacuna, and the distrust of the legal system and its punishments in the stated penal code. Put it differently, organized trans-national criminals have turned to women trafficking not only because it is 
profitable but also because the legal penalties for this new form of slavery is less severe than those for drug trafficking or gun running.

While Nigeria remains a signatory to all treaties against women dehumanization, it is imperative to admit that the world's attention is currently being directed at the identification and elimination of all kinds of trafficking and smuggling, particularly of women. Regardless of the assurances given by institutions, professional organizations, and motivated individuals to halt this problem, trafficking and smuggling for sexual exploitation have gained unsavoury reputation in Rivers State where many families have embraced trafficking of their daughters as the most lucrative economic alternative to escape extreme poverty. As the proceeds of trafficking run into millions of naira, mothers who once upheld the sacredness of their body until marriage are proudly extolling the sexual prowess of their daughters as better-yielding economic venture than other low-skill professions.

It is against this backdrop that this research seeks to address the menace of women trafficking and the implications on the Nigerian society with a decisive approach to halting it, particularly in Rivers State where it is presently rearing its ugly head having migrated from Edo State.

\subsection{Statement of the problem}

Trafficking is not new phenomenon. As a demand-driven global business with sex as its primary commodity, the huge number of female undergraduates and other college girls being trafficked has become an embarrassing, degrading and dehumanizing. It is indeed vexing to observe that pecuniary gain is the drive behind trafficking in women. As a result, young female undergraduates, including graduates and other college girls are elated at being trafficked. Daily reports state that in many cases, these young women once out of their neighbourhoods go into prostitution. With the proceeds running into millions of naira, parents, mothers who once uphold the inviolability of their body until marriage are at the present time extolling the sexual adventures of their daughters; encouraging them to offer their' bodies to every Tom, Dick and Harry as it seems better-yielding economic venture than other low-skill, labour-intensive professions. Regrettably, the menace has assumed the position of modern day slavery. Admittedly, poverty has erroneously been seen as the principle driving force behind this trade, but in reality, the motive behind this odd desire is borne out of greed, and impatience. Basically, with the frequency that trafficking has assumed in the country, the future of our daughters is certainly bleak if nothing is done to halt the menace

Generally, the objective of this study is to examine the incidence of trafficking in women which has increased in Rivers State, particularly in Okrika, Obio Akpor, Ikwere, Oyigbo, Ogubolor, Etche and Eleme, and certain other districts in Port Harcourt such as Choba, Rumukeni, Rumosi, Buguma and Andoni and efforts made to combat the menace of women trafficking and the implications on the Nigerian society with a decisive approach to halting it, particularly in Rivers State where it is presently rearing its ugly head having migrated from Edo State.

\subsection{Hypotheses of the study}

Hypotheses constitute the anchor of every research because they enable researchers to arrive at definite conclusions about questions raised in researches and by so doing facilitate the achievement of research objectives. For this study, the following three hypotheses would guide the study. In other words, they would guide the researcher on the type of data to collect, and how to state in order to achieve the objectives of the study.

\section{Hypothesis one}

Trafficking in women for sexual exploitation is not an economic activity driven by profit motives

\section{Hypothesis two}

Trafficking in women does not involve health risks such as HIV/AIDS syndrome and psychological trauma

\section{Hypothesis three}

There is no significant relationship between trafficking in women and human rights violation

\subsection{Significance of the study}

The first significance of this study is in its ability to provide empirical data on the consequences trafficking in women could have on women and society in general, and more specifically on the security of women. This study thus constitutes additional literature to already existing body of knowledge, as well as provides theoretical standpoint on not just the issue of human rights violations but on gender studies generally. Furthermore, it would serve to inform society members on the general dangers women trafficking could pose for women, and more specifically, its consequences on their health. 


\section{METHODS AND MATERIALS}

The study area of this research was conducted in Okrika, Obio Akpor, Ikwere, Oyigbo, Ogubolor, Etche, Eleme, and Port Harcourt City (Choba, Rumukeni, Rumosi, Buguma and Andoni) all in Rivers State. Survey research design was employed in this study. The reason for this research design is that it has the ability to collect large samples from the population, describes, and interprets the relationships that exist between the variables under study. Substantiating, Denga and Ali (1998) uphold that survey research design describe, and interpret the relationships that exist between the variables under study. Data for this study was gathered through the primary and secondary methods of data collection. In employing the primary method, a well structured questionnaire was used to elicit responses from respondents for the sole purpose of the study. The questionnaire was divided into two sections, namely section A and section B. Section A was made up of questions covering the personal data of the respondents, while section B was structured to address issues in the hypotheses and to satisfy the objectives of the study. Furthermore, the study made use of secondary source of data collection. In using this method books, journals, newspapers and the internet were consulted. Sampling is used here to denote the collection of information and drawing of inference about an entire population. The study employed the judgmental sampling technique that enabled the researcher to apply his discretion in selecting the respondents used in the study. This is essential because of the fact that the sampled respondents are made up of respondents who understood what the focus of the study meant. The target population involved in this study consisted of respondents purposively drawn and each population area was given equal and independent opportunity to be selected or not selected in the study. In essence, respondents were drawn from each of mentioned areas, and in all, 200 respondents were drawn by implication, each designated area produced 25 respondents. Questionnaire method was employed to find answers in line with the hypotheses formulated. The content and face validity of the instrument ensured questions that respondents were familiar with the subject matter were asked. The importance of data analysis in any research study cannot be over emphasized; this is done with a view to testing the hypothesis formulated in this study as well as meeting the overall objectives of the study. To test the hypothesis, the statistical method used is simple percentage and Pearson correlation coefficient analysis. The simple percentage was used to analyses general data while the Pearson moment correlation coefficient analysis was used to test the hypothesis formulated for the study. Test was carried out at 0.05 level of significance

\section{THEORETICAL FRAMEWORK}

\subsection{The Structural functionalist Perspective}

Of all theories, structural functionalism, simply called functionalism, is adopted in this study. It is a broad perspective that sets out to interpret society as a structure with interrelated parts. Herbert Spencer (1820 - 1903), presents these parts of society as organs that work toward the proper functioning of the entire body. In the most basic terms, it simply emphasizes the effort to impute, as rigorously as possible, each feature to function as a supposedly stable, cohesive system. Aside Spencer, some other prominent scholars including Auguste Comte, Émile Durkheim, Talcott Parsons, Robert Merton, Kingsley Davis and Wilber E. Moore to mention but a few have delved into different aspects of functionalism.

The basic assumption of the theory is that the society is a living organism made up of component parts, which function harmoniously for the survival of the whole system. If any part fails to contribute to an identifiably useful function, neither does it promote value consensus among members of the society - it will not be passed on from one generation to the next. The basic tenets of structural functionalism include the following: firstly, it entails interaction among various parts within the system. There is inter - dependence of various parts within the system. This means that the function of a part of a system usually affects the system as a whole. Accepting the foregoing as a fact, the system of sexual morality that seemingly condemns trafficking in women in the open encourages it from the other side to ensure the state of equilibrium unknowingly. By this unintended action, sexual activity is splits into two, namely, "consequential sex" (with one's spouse), and "inconsequential sex" (with prostitutes). With this division, men to go to trafficked women (prostitutes) if they want to have "insincere sex". This explains why trafficking in women has continued to flourish in Nigeria despite all efforts to combat the menace. Besides, since anal or oral sex is seen as an immoral activity to have with one's spouse, the continued viewing of pornography has necessitated men out of curiosity to indulge in it with trafficked women. Since wives at homes are responsible and respectable and cannot be subjected to any degrading and dehumanizing sexual acts which the 
man often craves to explore for curiosity sake. The sex industry through the trafficking in women process offers these services, and men are usually most willing to go for them. Thus, the existence of trafficking despite all efforts to change the narratives aids the society not to over stress sexual morality, but also sexual immorality to achieve stability. In effect, implication is that the moral order creates a demand for trafficked women to fulfill this immoral desire (this sexual exploit).

The relevance of functionalism to this study rests on the fact that trafficking in women (prostitution) exists because the moral system paradoxically encourages it and in turn serves the important function of preserving the society from breaking apart.

\section{CONCEPTUAL CLARIFICATIONS}

\subsection{The concepts of women trafficking and smuggling}

Human trafficking and smuggling are not the same; they are overlapping concepts. However, for a proper understanding of the terms 'trafficking' and 'smuggling' need to be elucidated. Many times, both terms have been used interchangeably without a clear distinction. While it is acknowledged that the distinction between the two is sometimes blurred, yet they differ in theory, and in particular in their human rights implications.

Trafficking generally denotes the coercion or forced movement of persons for the purpose of exploitation, with or without their consent. It is generally characterized by subsequent exploitation of those trafficked. On the other hand, the smuggling of migrants usually relates to the facilitated illegal entry into a State in a voluntary capacity through the paid services of a smuggler. In other words, in the case of trafficking, the trafficked person is a victim, whereas the smuggled is regarded as a client in the case of smuggling. In addition, whereas, smuggling is considered to be 'a crime against States', trafficking is seen as 'a crime against a person'. The importance of this distinction is embedded in the implications for the human rights of victims or clients of the perpetrators of these activities. For instance, it is argued that trafficking is an issue of migration with human rights implications as it involves protection of individuals, whereas smuggling is an issue of crime and border control as it encompasses protection of States. Hence, unlike trafficking, smuggling generally has not been considered a human rights issue. While, such recognition of the rights of victims of trafficking is welcome among human rights activists, however, it must be noted that smugglers often deceive individuals who have paid for their services. They often create a situation whereby those they have smuggled may be further victimized, either directly or their relatives in the country of origin.

In a nutshell, Carling (2009) defines human smuggling as "complicity in, or the facilitation of immigration in violation of local immigration laws and regulations." For UNODC (2005), human smuggling is "smuggling of migrants which involves the procurement of financial or other material benefits of illegal entry of a person into a state of which that person is not a national or resident". Hence, facilitation must occur for the purpose of profit in order to be referred to as human smuggling. Evidently, smuggling does not necessarily imply an element of exploitation. Essentially, it is often the result of an agreement between two parties - a prospective immigrant who lacks the opportunity to immigrate legally and human smuggler offering his services in the form of forged documents against payment. Often both parties are satisfied with the deal - the human smuggler receives the agreed payment and the immigrant gets to enter the country as intended. Corroborating, International Organization for Migration (IOM) (2006) describes human smuggling as the facilitation of entry into a third country in violation of immigration regulations, against payment. On the other hand, human trafficking is quite different from human smuggling because the former usually involves using of improper means like force, fraud or deception as against mutual agreement involves in the later. Beside this attempt to define it, UNODC (2005) sees it as "the acquisition of people by improper means such as force, fraud or deception, with the aim of exploiting them”, By this definition, trafficking denotes that people are forced, tricked or threatened into situations in which they are exploited either sexually, financially or through forced labour. At the international level, we have seen a number of instruments dating back to 1904 that have in one way or the other dealt with the problems of trafficking. While it is true that some of these instruments may not specifically deal with or mention trafficking, however, it is correct to say that, certain elements in those instruments reveal that trafficking has always been seen as taking place primarily for prostitution and sexual exploitation of women. However, it has been difficult to reach a consensus on how to define trafficking and it was not until the year 2000 that the UN General Assembly adopted a common definition, referred to as the Palermo Protocol, which defines human trafficking as: 
Trafficking in persons shall mean the recruitment, transportation, transfer, harbouring or receipt of persons, by means of threat or use of force or fraud, deception, or the abuse of power ... for the purpose of exploitation. Exploitation shall include, at a minimum, the exploitation of the prostitution or other forms of sexual exploitation, forced labour or services, slavery or practices similar to slavery, servitude or the removal of organs. While this formulation is widely accepted - the TIP Protocol has been signed by 117 countries.

An essential aspect of this definition is the phrase 'for the purpose of exploitation', reflecting the human rights concerns associated with trafficking. Other relevant international conventions on trafficking which Nigeria and Ireland are signatories to include: The Universal Declaration on Human Rights (1984); The Convention on the Rights of the Child (CRC, 1989); The Optional protocol to the CRC on the Sale of Child, Child Prostitution and Child Pornography (2002); The Convention on the Elimination of All Forms of Discrimination Against Women (1979); and The ILO Convention on Forced Labour and Minimum Wage (No. 182 of 1999).

However, new findings seem to suggest that the days of being forced, tricked or threatened are gone for good as women are consciously imploring to be trafficked for sexual labour; they are no more being forced, tricked or threatened into situations in which they are exploited either sexually, financially or through forced labour. With the expectation of bringing home some hard currencies to improve their immediate milieu, women are more relaxed offering themselves to be trafficked. As a result, women trafficking have become a demanddriven global business with a huge market for commercial sex. Thus, young female school leavers including female graduates prefer marketing their bodies sexually to other alternatives. Even when gainfully employed, seducing men and ensuring that their sexual prowess at first attempt is exceptionally satisfactory has seen many of these women/ladies erecting magnificent buildings and cruising fast automobiles. With this eye catching investments, understanding, traffickers it is the young women who are daily offering and pestering traffickers to facilitate their migration abroad to choice countries to live a fulfilled life on return. By implication, unlike previously, women are nowadays increasingly aware that they would market their bodies for money, an earnest desire, and for many, this is a dream come true; thus they must compete positively with anyone who dares them to prove that sexual explorations and exploitation is a better paying profession.

Pronto, Nigeria has become very notorious for women trafficking in Africa, and acquired a reputation for being one of the leading African countries in trafficking and smuggling of persons, particularly women with crossborder and internal trafficking. Admittedly, women trafficking cases in Nigeria have not been reported and documented. As such, there exist no comprehensive records to track the incidence in absolute numbers. However, conservative isolated records here and there indicate that well over two million women are trafficked annually out of Nigeria alone to confront the unimaginable hardships in their new destinations in the quest for a better life. Earlier, it was reported in the media that roughly 700,000 women and children were trafficked across international borders annually, of which approximately 200,000 were trafficked in Southeast Europe and the rest from Asia and Africa. Basically, the profitability of women trafficking hinges on the characteristics of the market for commercial sex. Though, some countries still deny the magnitude and inhuman treatments involved in women trafficking, especially as it affects their nationals. Even if its existence was admissible, it was mistakenly associated most often with women from the other countries, with maybe one or two countries close to them (Chukwu, 2016). Whether mistakenly associated with women from the other countries, with maybe one or two countries close to them or not, Chukwu states that trafficking in women has not only become an eyesore, but a global phenomenon.

Admittedly, trafficking in women for sexual exploitation has long been controversial, particularly with the Amnesty International's decision, in the fall of 2015, to support worldwide decriminalization of all aspects of sex trade: supplying, demanding, and mediating (pimping) transactions. This recent call, critics, on one hand, worry that decriminalization will facilitate and boost women trafficking. Contributing earlier to this contentious issue, UNODC (2009) says virtually every country in the world whether rich and poor is affected by this complex and clandestine crime against humanity. While admitting that trafficking in women can be a force for liberation-as well as for enslavement, globally, it has brought with it positive opportunities for women nowadays and at the same time, debt bondage. However, as poverty disproportionately affects women and their children (Baird, Vanessa, 2002), it is not unexpected to observe that women are being pushed to migrate in the hopes of acquiring economic security for themselves and their families. Although the push and pull factors of migration are similar for men and women, their migration experience differ greatly. 


\subsection{Causes of trafficking in women}

Basically, women trafficking are rooted in the push and pull factors of supply and demand equation. Even though these factors have a worldwide importance, they vary. Before delving into the pull and push factors, it is disheartening to observe that the quality of education in Nigeria's schools at all levels has fallen radically and there seems nothing teachers can do to halt female students from graduating half-way because the quest to traveling to Europe seems to dominate whenever two or three young female students meet; the lists of magnificent houses and investments acquired by a peer group who travelled to Europe seem to becloud their sense of morality and decency. Of disappointment, Illiteracy has been identified as one major cause for the boom in the sex trade. Just imagine the mad rush for money, and material possessions at all cost through the sex trade. Picture with the eyes of one's mind, if one will, the recognition and cheers accorded these school drop outs with sudden riches irrespective of how came the opulence. The wild adulation which, these young ladies enjoy after prostituting abroad is baffling. In a collaborative statement, Carling (2009) observes that young women often have a low level of education which may eventually dispose them off to the possibility of trafficking. Similarly, in Albanian and Kosovar, Omelaniuk (2005) argues that the low level of education among the young women shows clearly that illiteracy is a big factor which breeds the possibility of the lure into trafficking. Aside this, pressure from families are often favourably disposed to seeing that their daughters migrate because they often show more consideration towards the family than emigrating men, and become important resources to the family members back home in Nigeria.

In analyzing the push and pull factors of supply and demand equation, it is worthy to know that Nigeria has acquired a reputation for being one of the leading African countries in human trafficking with cross-border and internal trafficking (UNESCO policy paper, 2006). Sequel to this, it is generally acknowledged that trafficking of persons is the third largest crime after arms and the drug trade. Despite international institutions designed to halt the menace, the socio-economic crises in Nigeria have propelled the active participation of women without considering the consequences. This has negatively impacted on the upholding of discipline, morality and sanity in the once cherished ethos of the people prior to the emergence of the International trafficking of women for commercial sexual exploitation.

There are essentially two forms of women trafficking in Nigeria: the international form and the intra-national form. The international form of trafficking involves international syndicates who lure the female victims via job offers or any other sugar coated story that would convince the most doubting woman to be swept off her feet and taken to another country for prostitution. Succinctly, traffickers usually induce victims to migrate voluntarily with false promises of good paying jobs in foreign countries as models, artists and domestic workers. They advertise pretentious jobs, marriage proposal and other juicy opportunities abroad in the media. Studies have reported other methods of operation to include approaching women or their families directly with offers of well-paying jobs, elsewhere. Above all, they provide seemingly genuine transportation and false documents to get victims to their destination; traffickers subsequently charge exorbitant fees for these services, thus, creating life-time debt bondage for the young women.

\subsubsection{The Push Factors}

Of the 17 sustainable development goals, and 169 targets, eradicating poverty in all its forms and dimensions, including extreme poverty, is the greatest global challenge and an indispensable requirement for sustainable development. Nigeria is the largest oil producer in Africa and the eleventh largest in the world, yet it is rated as one of the poorest countries in the world. This is vitally so because people are the real resource of any nation and for whom development should centre on ultimately. For instance, available data from the Nigerian Bureau of Statistics (NBS) shows that more than $70 \%$ of persons in Nigeria live below the poverty line of 1 USD per day (specifically 112 million live in relative poverty).The gap between the rich and the poor, in terms of income inequality (from 0.429 in 2004 to 0.447 in 2010), continues to widen, in spite of its huge natural and material resources (Iruonagbe, et al, 2015)

Prior to this era, it will be recalled that by the 1980s, Nigeria was already in the midst of economic decline especially in the prices of crude oil, which was the country's main source of foreign exchange earnings. With the continued decline in the purchasing power of the naira and low capacity utilization of industries, poverty emerged as a permanent feature of majority Nigerians. Urban dwellers especially public sector employees were hard hit by the decline in their real incomes by almost 50 per cent. Unfortunately, the harsh economic conditions exacerbated 
by corruption put the citizens in a perilous state. Undoubtedly, poverty arising from inequalities in living standards amongst Nigerians widened over time. In other words, the inability to meet basic needs like education, health care and poor physical conditions reflected the deepening poverty amongst Nigerians, and this, unceremoniously ignited the search for greener pastures anywhere.

Cognizant of this ugly situation, the government in power still went ahead to introduce the structural Adjustment Programme (SAP), and implemented the International Monetary Fund (IMF) conditionality attached to it. This further led to many unpleasant consequences such as workers losing their jobs through retrenchment, many people not being able to afford most of the necessities of life due to wage cuts and withdrawal of subsidies, skyrocketing inflationary situation occasioned by currency devaluation, high rates of unemployment, high inflationary rate; low purchasing capacity of the naira; job and food insecurity led to unprecedented protests by the aggrieved interest groups. As this uncertainty continues, women, particularly those who had sojourned to Europe to buy gold, shoes and clothes to sell in Nigeria in the hopes of acquiring economic security for themselves and their families were hard hit by the depreciating exchange rates of the country's currency (naira). Therefore, while struggling to live out there, the women, on discovery that they were highly sought after for their sexual prowess, engaged in selling their bodies as past time while waiting for visible progress in the economic policies of government.

Unfortunately, it never came and what started as pastime activity soon snow-balled into becoming a lucrative economic alternative venture to be actively involved. The economic sex industry emerged. Fundamentally, greed, unemployment and poor economic situations are other factors that can make women fall victims of trafficking. For instance, Omelaniuk (2005) observes that some of the victims were unemployed prior to migration. Those that were employed earned less that 30 dollar a month. Thus the economic circumstances appear to be dire enough to call for survival strategies such as those offered by migration. Update (2006) gives an illustration of how profitable the sex trafficking is as against the other legitimate means of earning. For instance, a young woman prostituting in Europe can earn in few months with less efforts, what she would make in 12 years working in a farm, or public or private entities in Nigeria. Hence, the trade of sex trafficking is highly profitable one. In a nutshell, the lack of opportunities to improve the economic conditions of Nigerians, and other desperate circumstances became the major push factors in the incidence of trafficking.

\subsubsection{The Pull Factors}

The laws of supply and demand are one of the key pull factors that blossomed trafficking in women. As earlier stated, while struggling to survive in Europe and awaiting for visible progress in the economic policies of government, there seemed to have been an increase in the demand for black women prostitutes of all shades in the developed world because they could provide maximum satisfaction in bed and are reputable to last longer during sex. Besides, the fear of AIDS during this era made preference for non-Europeans in the sex trade higher than ever before. The demand for prostitutes from supposedly less AIDS prone areas like Nigeria and other African countries consequently increased. In addition, the love for dark skinned ladies was a big pull factor for trafficking in women. Consequent upon this, one could contend that the demand for Nigerian women abroad was hinged on their sexual prowess, dark skin, and being less AIDS prone. Aside this, many countries are involved and these countries lack uniform definition of what trafficking in women is. However, trafficking in women does not appear as a colossus that cannot be prevented and controlled. The first preventive measure is the reduction in the levels of poverty and illiteracy. The increasing cases of trafficking in women would be reduced if the nations tackle ignorance, illiteracy and poverty and provide job opportunities for the masses, especially, the young women that are vulnerable (The Guardian, 2009).

\subsection{The Effects (consequences) of human trafficking}

Perhaps, it will be necessary to ask the question: what does trafficking in women portend for the socioeconomic development and survival of the Nigerian state and citizens? The question is premised on the fact that there is a direct linkage between women trafficking and violation of human rights. In this sense, the issue of developing the economy for the good of the citizenry cannot be dependent on remittances from trafficking in women because they serve as external funding for developing countries; Nigeria must be an exception. Besides, the cost of trafficking in women is most difficult to measure. The cost is more than just dollars being remitted from the sex trade. It must also include the damage done to women. No matter the arguments against trafficking, there are countless illiterate young women that seem to find no alternative to improving their lots but to engage in 
prostitution. These include runaway young girls that pimps have taken to market for profit taking. They intentionally provide the girls with drugs and when addicted, they immediately conclude that there is no other way to survive than prostituting themselves for their pimps. Unfortunately, on discovery of their real status, these young girls are psychologically damaged because they had believed their pimps are actually their friends and lovers.

Along with the cost to trafficking in women comes the crime that goes with in trafficking in women. Often prostitutes are raped and since they cannot report the crime to the police, they live with the trauma. In addition, these young women are both victims and offenders of robbery and theft. Often the customer is robbed and cannot report the crime to the police because of the embarrassment of patronizing these girls. On the other hand, the girls cannot also report when they are robbed because the police would be unsympathetic and view the offense as being civil. What is more, the effects of trafficking in women are enormous and very pathetic because the exploitations are dehumanizing and a clear violation of human rights. Victims are subjected to violence, threats and other forms of physical and mental abuse including being under servitude and debt bondage.

\section{ANALYSIS OF RESULTS}

The significance of data analysis in any research study cannot be over emphasized; this is done with a view to testing the hypothesis formulated in this study as well as meeting the overall objectives of the study. To test the hypothesis, the statistical method used is the Pearson correlation coefficient analysis. The Pearson correlation coefficient analysis will help to explain the closeness of the relationship between two or more variables. The variables are said to be correlated when the movement of one variable is accompanied by the movement of another variable. The following formula is used to calculate the Pearson $r$ correlation: $r_{x y}=$ Pearson $r$ correlation coefficient between $\mathrm{x}$ and $\mathrm{y} . \mathrm{n}=$ number of observations, and $\mathrm{x}_{\mathrm{i}}=$ value of $\mathrm{x}$ (for ith observation)

\subsection{Test of hypotheses by hypothesis and presentation of results}

In our bid to test each of three study hypotheses formulated for this study, each hypothesis is re-stated in the null and alternate forms noting their independent and dependent variables. The variables as well as the statistical analysis technique adopted to test the hypotheses were identified and presented. The 0.05 level of significance was used for the statistical testing of each of the hypotheses.

\subsubsection{Hypothesis one}

Ho: Trafficking in women for sexual exploitation is not an economic activity driven by profit motives

$\mathbf{H}_{1}$ : Trafficking in women for sexual exploitation is an economic activity driven by profit motives

The independent variable in this hypothesis is trafficking in women for sexual exploitation while the dependent variable is economic activity driven by profit motives. The hypothesis is tested using Pearson Product Moment Correlation and the result of the analysis is presented below.

TABLE 5.1: Pearson correlation coefficient analysis of Trafficking in women and Economic activity driven by profit motives $(\mathrm{N}=\mathbf{2 0 0})$

\begin{tabular}{lllll}
\hline Variables & $\Sigma \mathrm{X}$ & $\Sigma \mathrm{X}^{2}$ & $\Sigma \mathrm{XY}$ & r-value. \\
& $\Sigma \mathrm{Y}$ & $\Sigma \mathrm{Y}^{2}$ & & \\
\hline Trafficking in women & 1721 & 4978 & & \\
& & & 36745 & $0.50^{*}$
\end{tabular}

Economic activity driven by profit $1536 \quad 4978$ motives

Significant at .05 level, critical $\mathrm{r}=.195$, d.f 98

The result of the analysis revealed that the calculated r-value of 0.50 is higher than the critical r-value of .195 at .05 level of significance with 98 degree of freedom. With this result the null hypothesis was rejected. This result therefore means that trafficking in women is an economic activity driven by profit motives

\subsubsection{Hypothesis two}

Ho: Trafficking in women does not involve health risks such as HIV/AIDS syndrome and psychological trauma 
$\mathbf{H}_{1}$ : Trafficking in women does involve health risks such as HIV/AIDS syndrome and psychological trauma

The independent variable in this hypothesis is trafficking in women while the dependent variable is health risks such as HIV/AIDS syndrome and psychological trauma. This hypothesis is tested using Pearson Product Moment Correlation and the result of the analysis is presented below.

TABLE 5.2: Pearson correlation coefficient analysis of trafficking in women and health risks such as HIV/AIDS syndrome and psychological trauma $(\mathrm{N}=\mathbf{2 0 0})$

\begin{tabular}{lllll}
\hline Variables & $\Sigma \mathrm{X}$ & $\Sigma \mathrm{X}^{2}$ & $\Sigma \mathrm{XY}$ & r-value. \\
& $\Sigma \mathrm{Y}$ & $\Sigma \mathrm{Y}^{2}$ & & \\
\hline Trafficking in women & 1808 & 6493 & & \\
& & & 39973 & 0.45 \\
Health risks and trauma & 1536 & 4978 & & \\
\hline
\end{tabular}

Significant at .05 level, critical $r=.195$, d.f 98

The result of the analysis revealed that the calculated r-value of 0.45 is higher than the critical r-value of .195 at .05 level of significance with 98 degree of freedom. With this result the null hypothesis is rejected. This result therefore implies that there is a relationship between trafficking in women and health risks such as HIV/AIDS syndrome and psychological trauma

\subsubsection{Hypothesis three}

Ho: There is no significant relationship between trafficking in women and human rights violation

$\mathbf{H}_{1}$ : There is a significant relationship between trafficking in women and human rights violation

The independent variable in this hypothesis is trafficking in women while the dependent variable is human rights violation. Pearson Product Moment Correlation is used in the analysis and the results presented below.

\section{TABLE 5.3: Pearson correlation coefficient analysis of trafficking in women and human rights} violation $(\mathbf{N}=\mathbf{2 0 0})$

\begin{tabular}{lllll}
\hline Variables & $\Sigma \mathrm{X}$ & $\Sigma \mathrm{X}^{2}$ & $\Sigma \mathrm{XY}$ & r-value. \\
& $\Sigma \mathrm{Y}$ & $\Sigma \mathrm{Y}^{2}$ & & \\
\hline Trafficking in women & 1647 & 7285 & & \\
& & & 34857 & $0.48^{*}$ \\
Violation of Human rights & 1536 & 4978 & & \\
\hline
\end{tabular}

Significant at .05 level, critical $r=.195$, d.f 98

The result of the analysis revealed that the calculated r-value of 0.48 is higher than the critical r-value of .195 at .05 level of significance with 98 degree of freedom. With this result the null hypothesis is rejected. This result therefore means that there is a relationship between trafficking in women and human rights violation

\section{DISCUSSION OF FINDINGS}

The result from the first hypothesis reveals that trafficking in women for sexual exploitation is an economic activity driven by profit motives. The act has long ceased to be pleasurable and emotional. Nowadays, it has become just another business proposition. For trafficked victims, the sex act is no longer cherished and enjoyed but bitterness towards men for not cuddling them or showing affections as their primary intention is sex only. Although, many reasons have been adduced for this evil, but the level of poverty which has pervaded our communities (Guardian, 2009) stands out clearly as the basis for the sex business. Writing on sex trade, Omelaniuk (2005) observes that some of the victims were unemployed prior to migration. Those that were employed earned less that 30 dollar a month. Thus the economic circumstances appear to be dire enough to call for survival strategies such as those offered by prostitution abroad. Update (2006) says a young woman prostituting in Europe can earn in few months with less efforts, what she would make in 12 years working in a farm, or public or private entities 
in Nigeria. Hence, the trade of sex trafficking is lucrative, and highly profitable business whether forced into it by economic circumstance or not. In a nutshell, these young women, who are either voluntary or coerced into the sex industry seem to find prostitution preferable to whatever alternatives are available to them, i.e., to their outside option. For them, the income from the illicit sex trade equals their forgone income from alternative job opportunities. Empirically, selling their bodies seem better-paid than other low-skill, labour-intensive professions. Based on this, the worrying statistics from trafficking shows that an estimated $87 \%$ of women are trafficked (UNODC, 2006) for commercial sexual activity. This figure, we may argue, is a conservative estimate of the actual number of women trafficked, especially in this age and time where many young girls are willingly offering themselves to be trafficked for pecuniary reasons. Regrettably, this seems to be the most terrifying and dehumanizing aspects of the danger, not necessarily because it has become a purely economic activity in the last three and half decades, but that its assumed status as a modern day slavery with compensations in foreign currencies is worrisome. While exact data are hard to come by, UNESCO (2004) estimates that the number of trafficked persons range from 500,000 to two million per year, and a few organizations has estimated that up to four million persons are being trafficked every year. Going by the trend of the trade, these statistics are conservative estimates of the actual number of women trafficked. For some scholars, worldwide estimates on trafficked human persons, particularly women are always imprecise, but it has been suggested that nearly 30 million of trafficked persons live currently in servitude. Writing, José Alcalá, M. et al., (2006) state that trafficking has developed into a highly profitable business that generates an estimated US\$7-12 billion per year. Nevertheless, the bone of contention is not the conflicting or varying figures one may have, but the effects of the alarming number of trafficked women on the Nigerian society. But as it stands today and as it were yesterday, trafficking dehumanizes the dignity of womanhood, and there is absolutely no doubt about that. Corroborating this assertion, Divorkin (1992) stated that when men use women in prostitution, they are expressing a pure hatred for the female body. Evidently, Divorkin's submission seems to reinforce the stereotypical views about women as sex objects which can be used and abused by men, and by implication, further entrenching the existing patriarchal societal order. This, notwithstanding, it surprises many why the economic gains accruing from the trade seems to ignore the fact that Nigeria as a country, is a signatory to all forms of devaluation against women. The puzzle continues: How did Nigeria become a country of origin, transit, and destination for all forms of trafficking detrimental to women despite the fact that she has legislated against trafficking of persons?

From the second hypothesis, the analysis of data shows that there is a significant relationship between trafficking in women and health risks such as infection of HIV/AIDS and psychological trauma. In other words, some of victims contract HIV/AID and ever remain psychologically traumatized and mentally enslaved. Essentially, the damage is serious because sexually transmitted diseases (STDs) are common and protection often neglected. Frequent drug use and the sharing of needles are not only prevalent but the living conditions hell to contend with. The sex slaves suffer physical harm from being beaten up by both their customers and their pimps. Substantiating, Ndaguba (2005) gives the break down analyses of the effects of trafficking in women. According to him, there is one case of unwanted pregnancy/abortion in every 5 out of 10 victims. In this vein, respondents unanimously agree that there are numerous mental and physical health dangers for trafficked victims. It is important to be aware that the physically immature bodies of these school drop outs are extremely vulnerable to many sexually transmitted diseases (STDs) due to forced and unsafe sexual activities. This heightens the risk of contracting HIV, as Burkhalter (2003) declares, up to a factor of 10. Most worrisome is the fact that the vulnerability of trafficked women to sexually transmitted diseases is compounded by their inability to receive medical services, and counseling because of their failure to understand or speak the language of the country their destination.

Result from the third hypothesis shows that there is a significant relationship between trafficking in women and human rights violation. From the data, victims' exploitations are not only enormous and pathetic, but dehumanizing and a clear violation of human rights as they are subjected to violence, threats and other forms of physical and mental abuse. It is plainly regarded as a crime against humanity in the statute of the International Criminal Court (Article 7.2) because these young women are trafficked for the purpose of sexual or labour exploitation and it is estimated that $87 \%$ of the trafficking is for sexual exploitation (UNODC 2006). Trafficking in human beings for sexual purposes is intimately linked to organized crime and is considered the second source of illicit profits for organized crime (European Commission 2009). From findings, it is observed that at least 3 
out of group of 5 young girls are not only forced to experience sex for the first time in their life, but are made to swear to an oath in a voodoo shrine against their wish not to disclose their humiliating ordeals. With this, they become mentally and psychologically enslaved from the onset. Aside this, victims are subject to violence, threats and other forms of physical and mental abuse. US Web (2006) states that the victims are usually under servitude and by extension, subjected to debt bondage. Governments throughout the world view human trafficking as a component of organized crime and the average punishment for trafficking of humans is comparable to other types of serious transnational crimes (Morrison and Crosland 2001). Corroborating, the erstwhile United Nations Secretary-General, Kofi Annan at an international conference on transnational crime said "trafficking of persons, particularly women and children, for forced and exploitative labour, including sexual exploitation, is one of the most egregious violations of human rights which the United Nations now confronts. Substantiating, Hegen (2004) asserts that victims are subjected to the three D jobs: dirty, difficult and dangerous. The cost of trafficking in women is most difficult to measure. The cost is more than just dollars being remitted from the sex trade. It also includes the damage done to women. No matter the arguments against trafficking, there are countless illiterate young women that seem to find no alternative to improving their lots but to engage in prostitution. These include runaway young girls that pimps have taken to market for profit taking. They intentionally provide the girls with drugs and when addicted, they immediately conclude that there is no other way to survive than prostituting themselves for their pimps. Unfortunately, on discovery of their real status, these young girls are psychologically damaged because they had believed their pimps are actually their friends and lovers.

Along with the cost to trafficking in women comes the crime that goes with in trafficking in women. Often prostitutes are raped and since they cannot report the crime to the police, they live with the trauma. In addition, these young women are both victims and offenders of robbery and theft. Often the customer is robbed and cannot report the crime to the police because of the embarrassment of patronizing these girls. On the other hand, the girls cannot also report when they are robbed because the police would be unsympathetic and view the offense as being civil. What is more, the effects of trafficking in women are enormous and very pathetic because the exploitations are dehumanizing and a clear violation of human rights.

\section{CONCLUSION AND RECOMMENDATIONS}

\subsection{Conclusion}

This study presents a concise summation of trafficking in women. Basically, the profitability of trafficking to a given country hinges on the characteristics of the national market for commercial sex. A crucial factor for the profitability of commercial sex is the legal framework surrounding it. Aghatise (2004) argues that it is impossible to combat trafficking where prostitution is sanctioned. Besides, organized crime has as its major goal to maximize profits and its success depends on there being exploitable markets (Morrison and Crosland 2001). The decision made by a trafficker depends on the profit potential. The more profit that can be made in a specific country, the higher is the likelihood that a person will be trafficked to that country. As, always, the profit is a function of revenues and costs. The revenues are a function of the price and the quantity sold and should therefore depend positively on the size of the market in and the per capita income in the destination country. The costs for the trafficker can be divided into costs for entering a country, such as travel and smuggling costs and costs for running the business once in the country, such as costly discretion etc. If the trafficker finds that the benefit exceeds the costs then the country's markets would be flooded with abundant supplies of women. One can hardly understand why Nigeria that signed the UNTP on December $13^{\text {th }} 2000$ and ratified it on 28 June 2001, still have her citizens deeply involved in the sex trade. As a state party, Nigeria accepted a declaration to prevent and combat trafficking in women and children and to punish components of the offence of human trafficking, but the reality on the ground seems to suggest otherwise. But trafficking in women still booms and has brought untold hardships to the victims. Thousands of women have been denied their basic human rights in the process turning them into articles of trade. Notwithstanding, efforts should be continued against trafficking especially at the local levels and international community must realize that it is a problem that must be solved at all cost. Women trafficking must be seen and addressed as modern day slavery. It is a jet age servitude that must be extinguished. The entire world must wake up to the responsibility of cooperating with all the efforts to prevent and control this heinous crime. Remedies and strategies proposed by countries of origin or destination to combat trafficking and provide assistance to victims of trafficking should be approached from the angle of the promotion and provision of protection of the rights of women. In developing responses to trafficking, the various tiers of governments in Nigeria should provide rehabilitation centers for the victims of women trafficking. 


\subsection{Recommendations}

Based on the findings and analysis thereof, the following are the recommendations which the public, the law enforcement agencies and the government must get stuck in to ensure the total elimination of trafficking in women from the Nigerian, particularly in Rivers State.

i) The activities of the National Agency for the Prohibition of the Traffic in Persons and other Related Matters (NAPTIP) are hardly felt; a state of dormancy seems to characterize the agency for so long now. This calls for reorganization, proper and timely funding of the agency to make it more effective and goal oriented. Above all, the agency must ensure that it establishes constant links and exchanges information with other international agencies and bodies fighting human trafficking. This will facilitate its services in handling the cases of women trafficking in Nigeria.

ii) There should be programmes to inculcate in our young people the necessary skills, aptitudes and attitudes such that they can prudently and adequately utilize the resources and opportunities available to them for their own good and improvement of the society. In addition, the economic policies of government should be improved upon to arrest the problems of poverty and unemployment.

iii) Since trafficking for sexual exploitation is an economic activity driven by profit motives, government should through the National Assembly enact harsher laws against trafficking to make it less profitable. This recommendation is based on the effects it has had in Sweden and Norway where harsher laws to checkmate trafficking has yielded positive results.

iv) Furthermore, public awareness should be created about the evils inherent in women trafficking. In this vein, rallies should regularly be organized, with hand bills, pamphlets and other educative materials distributed to the public. Moreover, seminars and workshops should always be held in schools and other public places to sensitize and educate young ladies on the dehumanization in the sex trade

v) The judiciary should as a matter of urgency ensure that offenders found guilty are punished accordingly. In other words, legal reforms in the administration of justice must be done with as fast as possible. In addition, the police, judiciary and the public prosecutors should be given training to understand the nitty-gritty of gender analyses in order to incorporate into them into their programmes and ensure a new approach to halting the menace is achieved.

.Finally, individuals, corporate organizations and civil society organizations should assists in the re-integration, rehabilitation and counseling of rescued victims of trafficking. This calls for assistance, particularly financial to re-establish them in different vocations for them to find meaning to live without returning to be trafficked.

\section{REFERENCES}

Aghatise, Esohe "Trafficking for Prostitution in Italy: Possible Effects of Government Proposals for Legalization of Brothels." Violence Against Women, 10(10): 1126-1155, 2004

Arlacchi, Pino. UN Office for Drug Control and Crime Prevention. From his statement, as reported in Refugee Reports, Vol. 21. No. 5, 2000

Baird, Vanessa "Fear eats the Soul". New Internationalist, Issue 350, October. p. 10, 2002

Burkhalter, Holly "Sex Trafficking and the HIV/AIDS Pandemic, Physicians for Human Rights, Testimony before the House" International Relations Committee, p. 1-2, June 25, 2003 Accessed from: $<$ http://www.phrusa.org/campaign/aids/news062403

Caldwell, Gillian; Galster, Steven; and Steinzor, Nadia. Crime \& Servitude: An Expose of the Traffic in Women for Prostitution from the Newly Independent States. Global Survival Network. Washington, D.C., 1997 
Caldwell, Gillian; Galster, Steven; and Steinzor, Nadia. Crime and Servitude: An Expose of the Traffic in Women for Prostitution from the Newly Independent States Global Survival Network. p. 10, 1997

Carling, J. 'Migration, Human Smuggling and Trafficking from Nigeria to Europe Oslo": International Peace Research Institute, www.com.int/jahialwebdav/sue/myjahia site share, 2009 Accessed on: 21-03-2019

Chukwu, C.C. Fundamental of Sociology: An Introduction. Serenity Publishers, Lagos, 2016

Corner, Lorraine "A Gender Perspective to Combat Trafficking," Strategy Paper on an Integrated Approach to Livelihood Options for Women \& Girls, Seminar on Promoting Gender Equality to Combat Trafficking in Women and Children, Bangkok, 2002

Diana Wong, The Rumor of Trafficking: Border Controls, Illegal Migration, and the Sovereignty of the NationState, in Illicit Flows and Criminal Things 69, 76, 2005

Denga, D. \& Ali, A.. An introduction to research methods and statistics in education and social sciences.Calabar: Rapid Educational Publishers, 1998

European Union Press Release. EU urges higher priority for fight against trafficking in women and children. Brussels, Belgium, 2002

European Commission. "EU action against trafficking in human beings." Accessed online from: $<$ http://ec.europa.eu/justice_home/fsj/crime/trafficking/fsj_crime_human_trafficking_en.htm\#part_1.

Haaga, Paul T.; Aja, Elechi F.\& Chukwuemeka, Okoye A., International Journal of Peace and Conflict Studies (IJPCS), Vol. 2, (3):27-40, September, 2015. Website: http://www.rcmss.com.

Hegen, J. 'Third Committee: Social, Humanitarian and Cultural; International Cooperation for Social Development continue to grow, but challenges remain,2004.' www. The greelibray.com! Third + committee \%3A + social \% 2c + Hum. Retrieved on 2 1-03- 2009.

Hodge, D. and Leitz, C. "The International Sexual Trafficking of Women and Children: A Review of the Literature", Affilia, 22: 163-174, 2007

Iruonagbe, C.T., Imhonopi, D. \& Egharevba, M.E (2015) Higher Education in Nigeria and the Emergence of Private Universities. International Journal of Education and Research Vol. 3 No. 2 February

Janie Chuang, Redirecting the Debate over Trafficking in Women: Definitions, Paradigms, and Contexts, 11 HARV. HUM. RTS. J. 65, 1998

José A., M. et a 1. "State of World Population: A Passage to Hope". Women and International Migration. UNFPA.

Kara, Siddharth. Sex Trafficking: Inside the Business of Modern Slavery. New York, NY: Columbia University Press, 2009.

Katerina L. ".Combat of Trafficking in women and Forced Prostitution: Ukraine, Country Report", Vienna: Ludwig Boltzmann Institute of Human Rights, 1999.

Lord, Jennifer. EU Expansion could fuel human trafficking. United Press International. November 9,2002

Maetens F. "Crime, Violence, and Development Trends, Costs, and Policy Options in the Caribbean". A Joint Report by the United Nations office on Drugs and Crime and the Latin America and the Caribbean Region of the World Bank March 17, 2007

Manbe, Dagaci Aliyu 'Trafficking of Women and Children in Nigeria: A Critical Approach. American International Journal of Social Science Vol. 5, No. 3; June, 2016

Moffat, Peter G., and Simon A. Peters. "Pricing Personal Services: An Empirical Study of Earnings in the UK Prostitution Industry.” Scottish Journal of Political Economy 51(5): 675-690, 2004

Morrison, John \& Crosland, Beth. "The trafficking and smuggling of refugees - the end game in European asylum policy?” Working Paper No. 39, UNHCR, New Issues in Refugee Research, 2001

Ndaguba, C. 'Trafficking in Persons and Prostitution as an Impediment to Sustainable Development: The Nigeria Experience, Efforts and Challenges in Combating Crimes. A paper presented in Vienna - Austria at organized Seminar by Embassy of the Federal Republic of Nigeria in collaboration with Nigerians in Diaspora organization in Europe on 10th September, 2005

Nigerian Penal Code (Cap 345). Laws of the Federation of Nigeria. Section 405(d). Applicable in the Northern part of Nigeria, 1990

Niklas Jakobsson and Andreas Kotsadam. The Law and Economics of International Sex Slavery: Prostitution Laws and Trafficking for Sexual Exploitation. Norwegian Social Research (NOVA) and University of Gothenburg, Sweden, Box 640, SE-405 30, Gothenburg, Sweden, pp, 1.29, 2010:

Nwagbara, E. N, "Issues in children's rights and court services: A compilation of Lecture Notes". University of Calabar, 2015

OMCTP. "Trafficking in Persons Report" (A report presented to the US Secretary of Democracy and Global Affairs by the office to monitor and combat trafficking in person, 2002

Omelaniuk, I. 'Trafficking in Human Beings.' A paper presented to United Nations Secretariat at the United Nations Expert Group Meeting on International Migration and Development, 6-8 July, 2005 
Osborn, Andy. Sex Traffic is Europe's Shame. The Guardian, March 9, 2001

Ritzier, G. Sociological Theory (4 ${ }^{\text {th }}$ edition), Singapore; McGraw Hill International Edition, 1996

Ruggiero, V. "Trafficking in Human Beings: Slaves in Contemporary Europe", International Journal of the Sociology of Law, 25, pp. 231-244, 1997

Salt, John. "Trafficking and Human Smuggling: A European Perspective.” International Migration, 38(3): 31-56, 2000

Salt, John \& Stein, Jeremy. "Migration as a Business: the Case of Trafficking." International Migration, 35(4): 467-489, 1997

Stephanie Farrior. "The International Law on Trafficking in Women and Children for Prostitution: Making it Live up to Its Potential”, 10 HARV. HUM. RTS. J. 213, 1997

Strøm, A. (2009). "A glimpse into 30 years of struggle against prostitution by the women's liberation movement in Norway", Reproductive Health Matters 17(34) pp. 29-37, 2009. http://www. unodc.org/documents/Global_Report_on_TIP.pdf.

The Guardian 'How Nigeria Gained Confidence of US.' Thursday, June 18 p17. 2009,

The Guardian 'Poverty, Illiteracy aid Human Trafficking says NAPTIP Chief. Friday, - December 11 P7, 2009

The Holy Bible, “Joshua, Chapter 2 verse 1”. The Gideons International. Nashville, TN, USA, 2003 UNESCO policy paper, 2006

The Protection Project. A regional snapshot on trafficking in Persons, Especially Women and Children and Children in Western Europe. November, 2002

United Nations Educational, Scientific and Cultural Organization. Trafficking Statistics Project. Accessed from http://www.unescobkk.org/fileadmin/user_upload/culture/Trafficking/project/Graph Worldwide_Sept_2004.pdf on 23/12/2019

U.S. Department of State. Victims of Trafficking and Violence Protection Act 2000,Trafficking in Persons Report. June. p. 1, 2002

United Nations Economic and Social Council. Integration of the Human Rights of Women \& the Gender Perspective. February. p. 24, 2000

United Nations. General Assembly. Document A/55/383. Refugee Reports, 2000

United Nations Human Rights Committee. Recommendation of the 1998 Session of the Working Group on Contemporary Forms of Slavery, 1998

Morrison, John. and Crosland, Beth. "The trafficking and smuggling of refugees - the end game in European asylum policy?" Working Paper No. 39, UNHCR, New Issues in Refugee Research, 2001

UNODC. 'Human Trafficking.' Accessed from: <http://www.secinet.info/index.pnp on 23/12/2019

UNDOC."Trafficking in Persons: Global Patterns." Available online: http://www.unodc.org/documents/humantrafficking/HT-globalpatterns-en.pdf., 2006

Update 'Nigerian Trafficking Trade, 2006, Available from: <http:// www.update.dklcfje /uidbase.nsf. Retrieved on 21032019

UNODC 'Human Trafficking' Available from: <http://www.secinet.info/index.pnp.2006

US web, “Trafficking in persons' www.uruguay.usembassy.gov/usaweb,2006. Retrieved on 21032019

Vatican Official Says Human Trafficking Now Is Worse than African Slave Trade, Nov. 14, 2006, Accessed from http://www.iht.com/articles/ap/2006/11/14/ europe/EU_GEN_Vatican_Human_Trafficking.php; 